\title{
Comparison Study of Various Type Artificial Reef Performance in Reducing Wave Height
}

\author{
Muhammad Aldhiansyah Rifqi Fauzi ${ }^{1}$, Haryo Dwito Armono ${ }^{2}$, Mahmud Mustain ${ }^{3}$, Aniendhita Rizki \\ Amalia $^{4}$ \\ Department of Ocean Engineering, Sepuluh Nopember Institute of Technology $y^{1,2,3}$ \\ Department of Civil Engineering, Sepuluh Nopember Institute of Technology ${ }^{4}$
}

\begin{abstract}
Most fishermen used inappropriate methods to sustain their livelihoods, severely destroying fishery resources. Furthermore, a lack of environmental protection and pollution prevention lead the best coastal and estuarial nurseries to become unhabitable. Several studies have pointed out that fish stocks in coastal waters could be no longer sufficient for the increasing fishing activity and consumption requests. Based on the 1950-2006 global statistics conducted by Food and Agriculture Organization of the United Nations (FAO) (2012).Artificial reefs are most often constructed to increase the efficiency of fishery resource harvest (Seaman and Sprague, 1991). In engineering practice, the stability of artificial reefs is an important issue in preventing the failure of reef units due to wave and current actions. Some of the artificial reefs have also been designed to serve as low-crested coastal protection structures (e.g. Dalrymple et al., 1991a; Ranasinghe et al., 2006). One particular advantage of these artificial reefs over the conventional submerged breakwaters is the fact that they are multi-purpose units and can be achieved with more cost-effective materials and environmentally friendly construction processes (Harris, 1995; Buccino et al., 2013). Artificial reef model keep looking for modification to get compatibility and efiiciency as submerged breakwater because the feasibility of artificial reefs for coastal protection is typically evaluated based on the percentage of surface wave height reductionWave transformation analysis in artificial reef do with consideration from some non dimensional variables. Wave transmission process defined with ratio betwwen transmission wave height and incoming wave heightThis research compares 5 types of Artificial reef in numeric model. There are hexareef, bottle reef, star reef, seadome and cube reef. They are tested with Indonesian wave steepness which has value between 0,0013 and 0,012 .
\end{abstract}

Keyword - Numerical, Modelling, Submerged Structure, Flow 3d, Transmission Coefficient

\section{INTRODUCTION}

$\mathrm{M}$ ost fishermen used inappropriate methods to sustain their livelihoods, severely destroying fishery resources. Furthermore, a lack of environmental protection and pollution prevention lead the best coastal and estuarial nurseries to become uninhabitable for fishes, mollusks, and crustaceans. Actually, the sustainability of the present fishery system is being questioned as most fishery resources are either overexploited or fully or heavily exploited (Garcia and de Leiva Moreno, 2001). Several studies have pointed out that fish stocks in coastal waters could be no longer sufficient for the increasing fishing activity and consumption requests. Based on the 1950-2006 global statistics conducted by Food and Agriculture Organization of the United Nations (FAO) (2012)

Artificial reefs are most often constructed to increase the efficiency of fishery resource harvest (Seaman and Sprague, 1991). Consequently, many maritime countries established dedicated organizations and invested significant funding in the scientific research and development of artificial reefs. These organizations systematically implemented coastal fishery renewal engineering projects. To effectively prevent fishery decline and to enhance the benthic environment, numerous artificial reefs of every type were deployed to increase coastal marine resources by providing a habitat and breeding grounds for fish. Cultivating fishery resources and preventing trawlers from invading coastal waters is anticipated to further protect coastal fishery resources (Terashima, 2006).

In engineering practice, the stability of artificial reefs is an important issue in preventing the failure of reef unit's due to wave and current actions. The stability of reefs and sediment erosion in the bottom of artificial reefs rely on the interactions among current-bottom material-reef systems. As a result, the study of flow field effects plays a leading role in enhancing recreational fishing and reducing beach erosion. Therefore, from a hydrodynamics aspect, it is an essential issue to study the flow field within and around the artificial reef to achieve optimal conditions for fish and to improve the performance of artificial reefs Coastal zone, one of the world's most influential lands in the making of human settlements, has been affected by shoreline erosion presenting in 163 coastal countries in the world (Martinez et al., 2007). In the USA, shoreline retreat could average up to $1.8 \mathrm{~m}$ and $0.9 \mathrm{~m}$ per year along the Gulf 
Coast and the Atlantic Coast, respectively (Beatley et al., 2002). A similar destruction can be found in Thailand where the threat of coastal erosion has led to a total loss equivalent to US \$156 millions per year - a very significant amount for a developing country (World Bank, 2006).

The development and management of coastal areas require more attention and supervision in the ongoing efforts to reserve this area. Often in the development of a region closely related to the utilization and reduction of carrying capacity of the area. This also affect the changes in the coastal areas. Coastal zones are dynamic, it means that beach spaces (form and location) change rapidly as a reaction to natural processes and human activities (Solihudin, 2010). In general, major coastal damage is caused by abrasion of seawater due to both the wave height and the large current. In addition, terms of ecosystem, coral reef damage resulted in the change of the food chain resulting in some species competing for survival and reducing the number of existing organism. Sakka et al (2011) convey about the need for the coastal area management planning, it is necessary to study the shoreling changes so that the development done has no impact on the environment.

In terms of their physical appearance and interaction with waves and hydrodynamics, submerged breakwaters are similar toartificial coral reefs that were originally used for ecological enhancements (e.g. Duedall and Champ, 1991). For this reason, some of the artificial reefs have also been designed to serve as low-crested coastal protection structures (e.g. Dalrymple et al., 1991a; Ranasinghe et al., 2006). One particular advantage of these artificial reefs over the conventional submerged breakwaters is the fact that they are multi-purpose units and can be achieved with more cost-effective materials and environmentally friendly construction processes (Harris, 1995; Buccino et al., 2013).

The feasibility of artificial reefs for coastal protection is typically evaluated based on the percentage of surface wave height reduction over a shore parallel array of the structures (e.g. Shirlal et al., 2006; Shirlal and Rao, 2007). The wave transformation process over an artificial reef may be described based on a comparable scenario of a typical submerged breakwater, particularly when the breakwater permeability is also considered. For this problem, a classic formula for wave damping over a porous media was introduced by Sollitt and Cross (1972). Losada et al. (1996) developed a 3D model based on eigenfunction expansion and a $2 \mathrm{D}$ mild-slope model for simulation of the process. Tsai et al. (2006) developed a numerical model based on a three-layer boundary value problem that treats both breakwater and seabed as porous media. Wiryanto (2011) derived a linear model based on the shallow-water wave equation with an additional term that could be treated to lump the damping mechanisms together. In all these studies, one common concluding remark is always on the relationships among the wave amplitude, the structure height, and the water depth that always appear to be the most influential to the structure performance in wave energy dissipation and surface wave height reduction

According to Putra, AOP et al (2013) examines the effect of sea level elevation on transmission coefficient and reflection of composite breakwater states that the lower sealevel is better for the composite breakwater to absorb the wave. Thaha et al (2015) investigated the porpous concrete-type block breaker and stated that the parameters affecting reflection, transmission and wave dissipation on breakwater are the design blocks that make water-solver breakers, wave height (Hi), Wave period (T), block length (B / L) and water depth (dk).

From the condition above, the purpose of this study is numerical model of artificial reef of it's performance and hydrodynamic condition.

\section{MATERIAL AND METHOD}

\section{A. Artificial reef}

Artificial reef model used in this research is consist from hexareef, star reef and bottle reef. Hexareef is a modification of a reef ball with a shape resembling a hexagonal prism with a larger base size. The hexareef design is equipped with 3 small holes on each side as well as a large hole in the center for the living creatures of the sea. In this study hexareef made with diameter base $\mathrm{m}$, diameter of the top $m$ and height of 1 meter.

Star shaped reef is an artificial reef form developed by Liu et al (2013). This artificial reef has a shape like a prism that has a base and a starlike cap. This starch shape has 8 ends with each thickness of $10 \mathrm{~cm}$. Star shaped artificial reef is mounted in a horizontal position and has a diameter of 1 meter.

Bottle reef is a combination of cylinder reef and turtle reef akhwady et al (2012). The shape of this artificial reef consists of two cylindrical reef cylinders with a lower diameter cylinder larger than the top to provide sufficient stability when exposed to waves and currents. Bottle reef has a height of 1 meter with a hole $10 \mathrm{~cm}$ diameter. While for large and small cylinders of $80 \mathrm{~cm}$ and $60 \mathrm{~cm}$ respectively. 

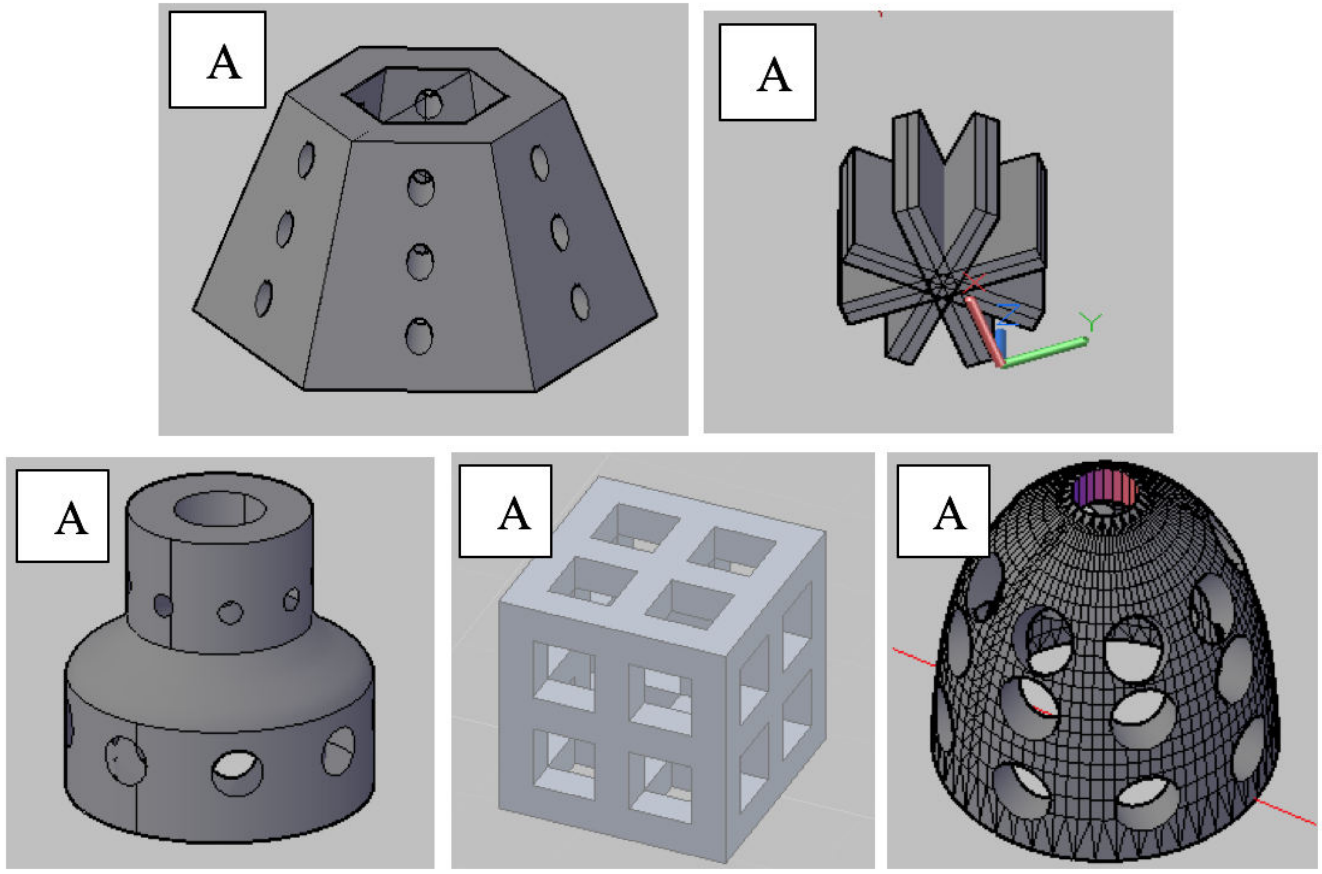

Figure 1 : Artificial Reef model a. hexareef; b. star reef; c. bottle reef., d. cube reef, e. seadome
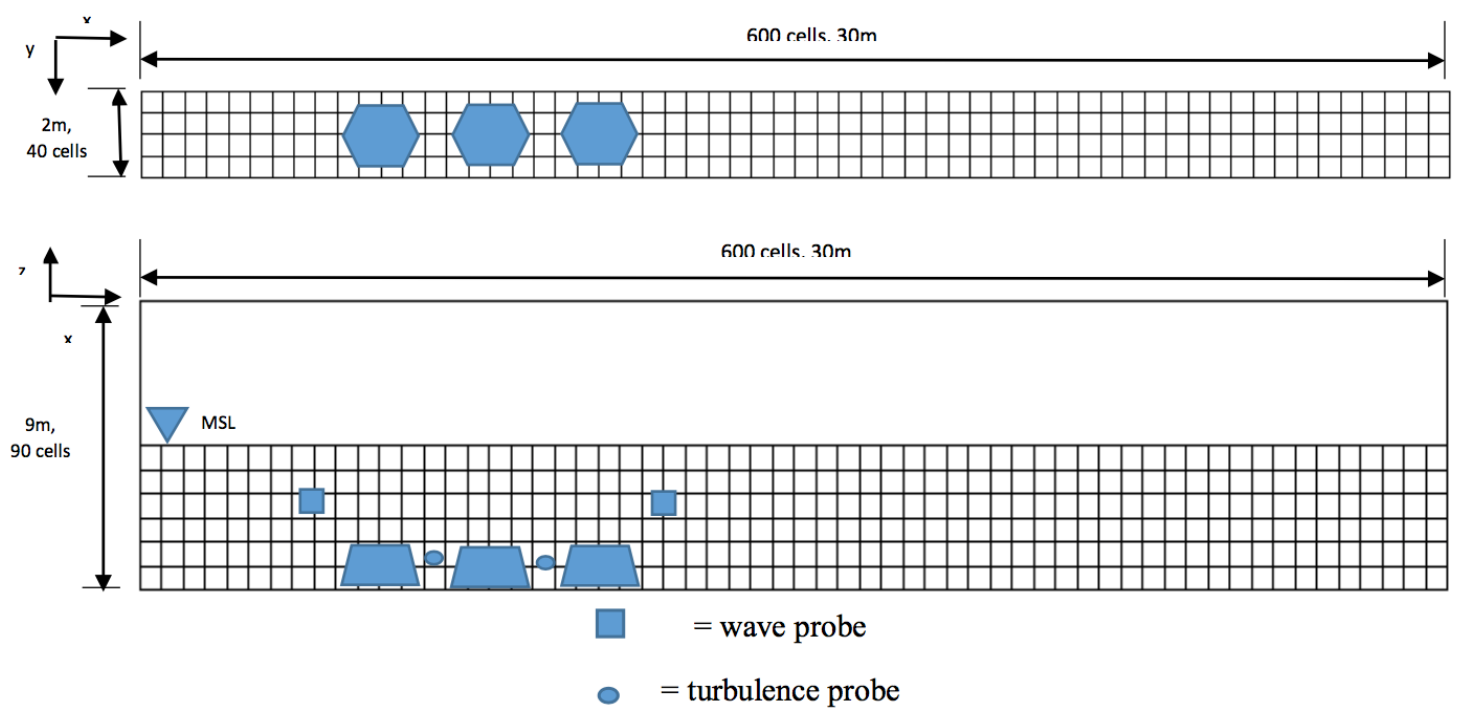

Figure 2 : Sketch plan of artificial reef and probe placement

Cube reef used in this research is a cube reef that used by Liu (2013) in the research, cube reef this is the artificial reef a cube with each side length 1 meters. On the side of the rib cube reef is designed with the thickness of the $10 \mathrm{~cm}$. on each side there is an additional cross form with the thickness of each $10 \mathrm{~cm}$ to increase the strength of the structure and increase the turbulence.

structure called as seadome this is the unit in the form of parts similar to the ball in circles. The artificial reef sedaome has many holes in the round about to the activities of the surrounding organisms. Seadome used in this research is taken from the research Srisuwan (2015). The size of the seadome used on this peneltiian has a total height 1 meters with the diameter of the base 1 meters. This Seadome have 24 holes on each portion with the diameter of the hole $10 \mathrm{~cm}$.

\section{B. Method}

As for some condition of research that conducted in this study, research on the performance of artificial reef is done through numerical model test. Numerical modelling of AR done with Flow3d program. This program has complete parameters to calculate AR performance.

Assessment of the performance of this artificial reef, there are 4 points that will be the reference in this study. Among other things: 1 meter in front and behind artificial reefs to measure wave heights and 2 points between artificial reefs to measure the intensity of 
turbulence that is around the artificial reefs such as figure 2 .

The reef was located on the ocean floor (see Figure 2) using a cartesian three-dimensional coordinate system $(\mathrm{x}, \mathrm{y}, \mathrm{z})$. Modelling tank has 30 meters length, 9 meters height and 1 meters width. Seabed is flat with no slope at modelling tank. In this research, depth of the sea is 3 meter at all condition. The computational grid used to cover the model consisted of 600 cells in 0-30 meters length (x), 90 cells for 9 meters height (z) and 40 cells for 2 meters width are used in y direction. Each reef has 1 meter height with geometry similiarities from the original model. Each model has 3 Artificial reef which placed in every $10.2,12.8$ and $15.4 \mathrm{x}$ direction. So, turbulence probes can be placed in between to see the turbulence that occurs between the artificial reef.

For initial condition, water depth was set at 3.0 $\mathrm{m}$ and the sea considered to be at rest. A stoke wave with $4 \mathrm{~s}$ period is used with various wave height start from 11.75 meter to test artificial reef with the effect of wave steepness.

\section{RESULT AND ANALYSIS}

Analysis of waveform transformations at breakwater is done bby considering various non-dimensional variables in graphical form. The wave transmission process defined as $\mathrm{Kt}$, which is the ratio between transmissi wave height $(\mathrm{Ht})$ and wave height $(\mathrm{Hi})$.

$$
\mathrm{Kt}=\frac{H t}{H i}
$$

With :

$$
\begin{array}{ll}
\mathrm{Kt} & : \text { Transmission coefficeient } \\
\mathrm{Hi} & : \text { Wave height }(\mathrm{m}) \\
\mathrm{Ht} & \text { : Wave tranmission }(\mathrm{m})
\end{array}
$$

\begin{tabular}{|c|c|c|c|c|}
\hline \multirow{2}{*}{ Artificial Reef } & \multirow{2}{*}{$\begin{array}{l}\text { wave } \\
\text { height }\end{array}$} & \multicolumn{2}{|c|}{ turbulence } & \multirow{2}{*}{$\begin{array}{l}\text { tranmission } \\
\text { coeffience }\end{array}$} \\
\hline & & point 1 & point 2 & \\
\hline hexareef & 1 & $44 \%$ & $64 \%$ & 0.59 \\
\hline hexareef & 1.25 & $99 \%$ & $67 \%$ & 0.46 \\
\hline hexareef & 1.5 & $113 \%$ & $60 \%$ & 0.40 \\
\hline hexareef & 1.75 & $104 \%$ & $54 \%$ & 0.38 \\
\hline cube & 1 & $62 \%$ & $75 \%$ & 0.61 \\
\hline cube & 1.25 & $54 \%$ & $75 \%$ & 0.47 \\
\hline cube & 1.5 & $57 \%$ & $66 \%$ & 0.40 \\
\hline cube & 1.75 & $62 \%$ & $87 \%$ & 0.38 \\
\hline bottle reef & 1 & $53 \%$ & $52 \%$ & 0.58 \\
\hline bottle reef & 1.25 & $81 \%$ & $52 \%$ & 0.57 \\
\hline bottle reef & 1.5 & $48 \%$ & $53 \%$ & 0.52 \\
\hline bottle reef & 1.75 & $46 \%$ & $53 \%$ & 0.48 \\
\hline star reef & 1 & $102 \%$ & $95 \%$ & 0.58 \\
\hline star reef & 1.25 & $109 \%$ & $101 \%$ & 0.49 \\
\hline star reef & 1.5 & $107 \%$ & $97 \%$ & 0.41 \\
\hline star reef & 1.75 & $127 \%$ & $113 \%$ & 0.34 \\
\hline seadome & 1 & $90 \%$ & $80 \%$ & 0.60 \\
\hline seadome & 1.25 & $77 \%$ & $76 \%$ & 0.50 \\
\hline seadome & 1.5 & $70 \%$ & $76 \%$ & 0.39 \\
\hline seadome & 1.75 & $71 \%$ & $78 \%$ & 0.33 \\
\hline
\end{tabular}

Because the turbulent movement associated with the vortex is thought to occur randomly. This movement can be characterized by using the concept of statistics. In theory, the velocity recorded continuously and the average rate can be evaluated through integrase. But in practice, speed measurement is discrete from a point. Average velocity, turbulence fluctuations, turbulence. Strength and turbulence intensity are defined as follows.

$\begin{array}{ll}\text { Velocity average } & \bar{u}=\int_{t}^{t+T} u(t) d t \\ \text { Turubulence fluctuation } & u^{\prime}(t)=u(t)-\bar{u} \\ \text { Turbulence strength } & U_{r m s}=\sqrt{\overline{u^{\prime}(t)^{2}}} \\ \text { Turbulence intensity } & U_{r m s} / \bar{U}\end{array}$

In this study, the value of turbulence is the main objective of the study because it can show how the flow around the artificial reef is moving. In the case of artificial reef development, it is important to create turbulence around the structure as it can mix the nutrients necessary for the living beings around it.

Table 1 : Numerical model result for artificial reef performance
Vortex turbulence causes fluctuations in partic velocity. For example, in longitudinal (u) and vertical velocities are measured in a point. The speed of the $t$ points varies with time caused by turbulen fluctuations. If the flow is steady and laminar, $\mathrm{u}=\mathrm{u}$ a $\mathrm{v}=\mathrm{v}$ within the given time period. In turbulent flo fluctuations occur as shown in the graph. In this case flow equation is described as.

$u(t)=\bar{u}+u^{\prime}(t)$

$v(t)=\bar{v}+v^{\prime}(t)$

The core equation is also called the Reync decomposition with the values $\mathrm{u}^{-}$and $\mathrm{v}^{-}$on the representing the mean and $\mathrm{u} \wedge^{\prime}(\mathrm{t})$ and $\mathrm{v}^{\wedge^{\prime}}(\mathrm{t})$ values turbulent fluctuations. (figure 3 )

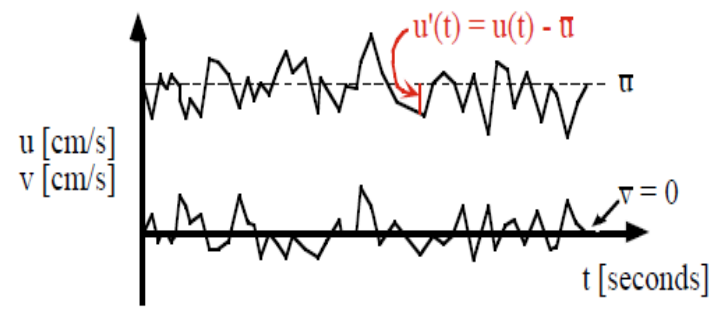

Figure 3 : example of turbulence read from a velocity graph 


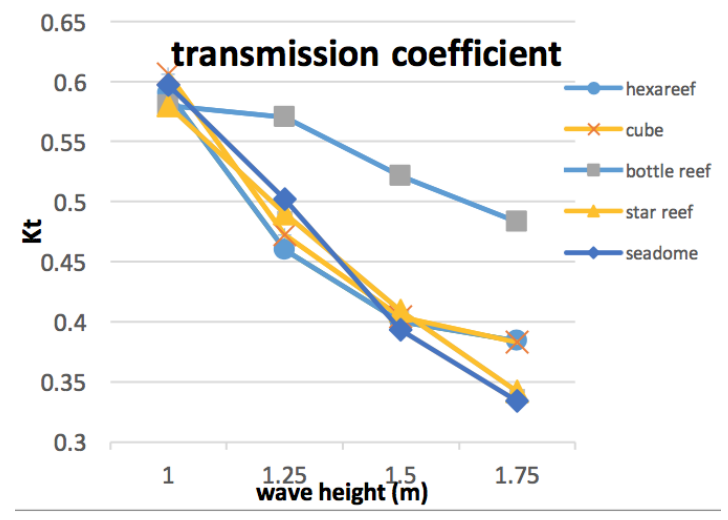

Figure 4 : Transmission coefficient in artificial reef

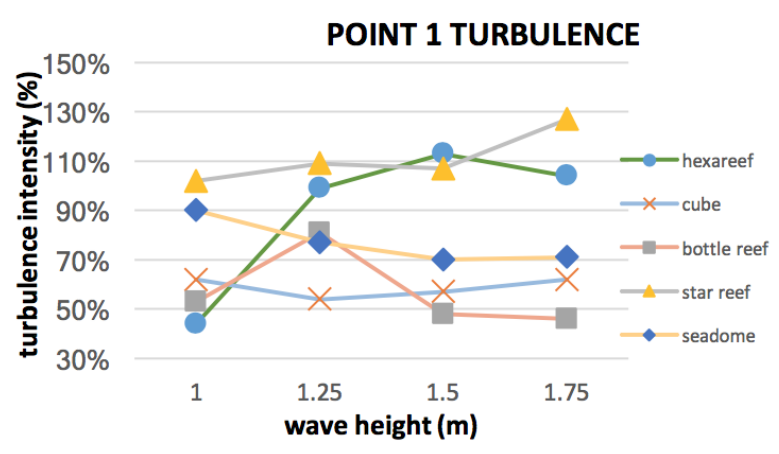

Figure 5 : turbulence intensity in point 1

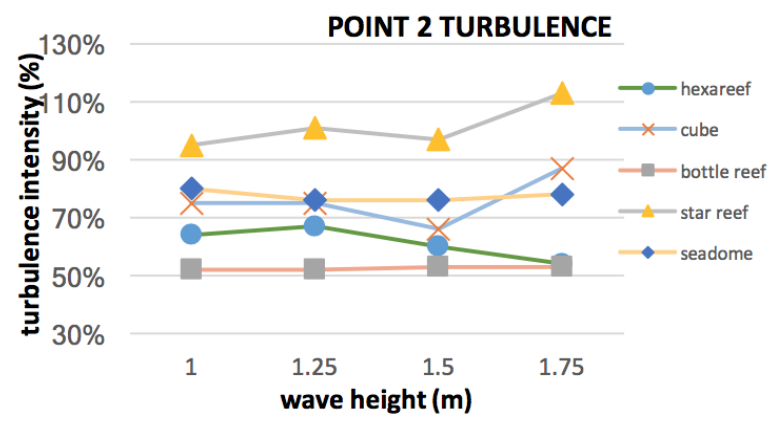

Figure 6 : turbulence intensity in point 2

In a transmision coefficient study performed on artificial reef. Seadome performance in reducing wave height is very good. In a $1.75 \mathrm{~m}$ seadome wave test resulted in a 0.33 coefficient transmission which is the lowest value compared to other artificial reefs. Even so this value is not so much with other artificial reefs except for poor bottle reef performance in this study.

The assessment of artificial reef performance from the turbulence intensity side performed in this research shows that the star reef performance is very good. Star reef can produce turbulence intensity value up to $130 \%$ in wave height $1.75 \mathrm{~m}$. This means that there is a lot of turbulence going on around the artificial reef that will blend the nutrients needed by the ecosystem around the artificial reef.
1. In terms of reducing wave heights, seadome performance has the best value by generating a tranmission coefficient of 0.33 . So that in the application of this seadome can be applied as in the tourist area so as to produce a smaller wave

2. The value of turbulence intensity at star reef is greater when compared with some other artificial reef so that with turbulence intensity value of $127 \% \%$ mixing nutrients contained in the sea will be easily mixed. This is very good for marine ecosystem breeding.

\section{REFERENCES}

[1] Akhwady, Rudhy., Mukhtasor., Armono, H.D., Musta'in, Mahmud. 2013. "Pengaruh Gelombang Reguler Dan Irreguler Terhadap Koefisien Transmisi Peredam Gelombang Ambang Terbenam Tipe Silinder Berongga (Bottle Reef )". Jurnal Kelautan Nasional Vol 3 No 3 April, Balitbang KKP RI

[2] Buccino, M., Calabrese, M., 2007. Conceptual approach for prediction of wave transmission at low-crested breakwaters. J. Waterw. Port Coast. Ocean Eng. 133 (3), 213-224.

[3] Buccino, M., Del Vita, I., Calabrese, M., 2013. Predicting wave transmission past reef ballTM submerged breakwaters. J. Coast. Res. Special Issue No. 65, 171-176

[4] Dalrymple, R., Driscoll, A., Ramsey, J., 1991 a. Laboratory Testing of the Beachsaver Breakwater System. Technical Report. Prepared for Breakwaters International, Center for Applied Coastal Research, University of Delaware.

[5] Ditton RB, Osburn HR, Baker TL, Thaing CE. Demographics, attitudes, and reef management preferences of sport divers in offshore Texas waters. In: Relini G, Ferrara G, Massaro, E, editors. SeventhInternational Conference on Artificial Reefs and Related Aquatic Habitats, Sanremo, Italy: Societa Italiana di Biologia Marina, 199. p. 241-53.

[6] Duedall, I., Champ, M., 1991. Artificial reefs: emerging science and technology. Oceanus 34 (1), 94-101.

[7] Food and Agriculture Organization of the United Nations (FAO), 2012. State of the World Fisheries and Aquaculture. Rome. 199-206. 〈http://www.fao.org/sof/sofia/index_en.htm〉.

[8] Garcia, S.M., de Leiva Moreno, I., 2001. Global overview of marine fisheries. In: Conference on Responsible Fisheries in the Marine Ecosystem, Reykjavik, Iceland, pp. 1-24.

[9] Harris, L. E., 1995. Engineering design of artificial reefs. In: OCEANS'95. MTS/IEEE. Challenges of Our Changing Global Environment. Conference Proceedings, vol. 2. IEEE, San Diego, CA, USA, pp. 1139-1148.

[10] Liu, Tsung-Lung., Su, Dong-Taur., 2013., Numerical analysis of the influence of reef arrangements on artificial reef flow fields., Ocean Engineering 74 (2013) 81-89.Liu, Yan., Zhao, Yun-peng., Dong, Guo-hai., Guan, Chang-tao., Cui, 
Yong., 2013. A study of the flow field characteristic around star shaped aritificial reefs. Journal of fluid and structures 39 (2013) 27-40.

[11] Martinez, M.L., Intralawan, A., Vazquez, G., Perez-Maqueo, O., Sutton, P., Landgrave, R., 2007. The coasts of our world: ecological, economic and social importance. Ecol. Econ. 63 (23), 254-272.

[12] Ranasinghe, R., Turner, I.L., 2006. Shoreline response to submerged structures: a review. Coast. Eng. $53 \quad$ (1), 65-79. Ranasinghe, R., Turner, I.L., Symonds, G., 2006. Shoreline response to multifunctional artificial surfing reefs: a numerical and physical modelling study. Coast. Eng. 53 (7), 589-611.

[13] Sakka, M. Purba, I.W. Nurjaya, H. Pawitan, dan V.P. Siregar. 2011. Studi perubahan garis pantai di delta sungai Jeneberang, Makassar. J. Ilmu dan Teknologi Kelautan Tropis: 3(2):112-126.

[14] Seaman, W., Sprague, L.M., 1991. Artificial habitat practices in aquatic systems, In Artificial Habitats for Marine and Freshwater Fisheries. Academic Press, Inc., San Diego, California, pp. 1-27.
[15] Solihuddin, T. 2010. Morfodinamika delta Cimanuk, Jawa Barat berdasarkan analisis citra landsat. Jurnal ilmiah.Geomatika, 16(1):77-85

[16] Sollitt, C. K., Cross, R. H., 1972. Wave transmission through permeable breakwaters. In: Coastal Engineering Proceedings. ASCE, Vancouver, Canada, pp. 1827-1846.

[17] Srisuwan, Chatchawin., Rattanamanee, Payom., 2015., Modeling of Seadome as artificial reefs for coastal wave attenuation., Ocean Engineering 103 (2015) 198-210.

[18] Terashima, H., 2006. Artificial reef projects: case studies in Japan and Senegal. The International Forum of the Development of Taiwan Artificial Reef. Biodiversity Research Centre, Academia Sinica, Taipei, pp. 85-90.

Thaha, A., Maricar, F., Aboe, A.F., Dwipuspita A.I., 2015. The Breakwater, from breaker wave to wave catcher. $8^{\text {th }}$ international conference on Asian and Pacific Coast (APAC) 2015, Procedia Engineering 116 (2015) 691-698. 